\title{
Evaluation Of The Mechanical Behavior Of Soils Subject To Laboratory Fusion Processes
}

\section{Evaluación del comportamiento mecánico de suelos sometidos a procesos de fusión en laboratorio}

\section{Avaliação do comportamento mecânico de solos sujeitos a processos de fusão em laboratório}

\section{Lesly Nathalie López Valiente ${ }^{1}$ \\ Luis Alberto Cáceres Cárdenas ${ }^{2}$ Andrés Leonardo Silva Balaguera ${ }^{3}$}

Received: May $11^{\text {th }}, 2020$

Accepted: July $28^{\text {th }}, 2020$

Available: September $2^{\text {th }}, 2020$

How to cite this article:

L. N. López Valiente, L. A. Cáceres Cárdenas, A. L. Silva Balaguera, "Evaluation of the mechanical behavior of soils subject to laboratory fusion processes " Revista

Ingeniería Solidaria, vol.16, no. 3, 2020.

doi: https://doi.org/10.16925/2357-6014.2020.03.03

Research article. https://doi.org/10.16925/2357-6014.2020.03.03

1 Faculty of Engineering, Professor of the School of Civil Engineering, GIISAG "Research Group in Seismic Engineering and Geoenvironmental Threats", Pedagogical and Technological University of Colombia.

Email: lesly.lopez@uptc.edu.co.

ORCID: https://orcid.org/0000-0001-6551-4756

2 Faculty of Engineering, Professor of the School of Civil Engineering, GIISAG "Research Group in Seismic Engineering and Geoenvironmental Threats", Pedagogical and Technological of Colombia.

ORCID: https://orcid.org/0000-0001-8399-7683

3 Faculty of Engineering, Professor, School of Civil Engineering, GICA "Research Group in Civil and Environmental Engineering", Pedagogical and Technological University of Colombia.

ORCID: https://orcid.org/0000-0001-5009-9721 


\section{Abstract}

Introduction: This article is the product of the research "Transformation of soils subjected to fusion processes in the laboratory", developed at the Pedagogical and Technological University of Colombia in 2018; this describes the results obtained concerning changes in the physical and mechanical properties of fine soils, especially clay soils, exposed to heating processes at different temperatures, when attempting to expand upon the knowledge of this process as a stabilization alternative.

Problem: Soils of recent origin are materials with a behavior that is frequently linked to the geological history. So, it is common to find soils with low resistance problems and excessive deformation; this makes it necessary to "improve" their geotechnical behavior.

Objective: The objective of the research is to quantitatively establish the resistance changes of a soil with fine granulometry when it is exposed to different temperature ranges.

Methodology: The project was based on a mixed methodology with an explanatory character. The variations of the soil under study are evidenced according to the phases defined in this article.

Results: In this article, the changes in the physical and mechanical properties of the soil, when it is melted and subjected to different tests, are exposed. As well, the variations of the results of the unconfined compression test and Atterberg Limits are presented.

Conclusion: To review the efficiency of the heat stabilization method as a technique of soil improvement with fine composition, taking into account the variations in the undrained cohesion of the soil.

Originality: This is the first that that this research has been carried out in the surrounding fine soils in the area of the lacustrine deposit of the City of Tunja, Boyacá, Colombia; contributing to the geotechnical characterization of the city and to the evaluation of this improvement technique.

Limitations: The samples, being fused, must be analyzed in rock test equipment. This contributed to the fact that the tests could not be performed at higher temperatures than those shown in this article.

Keywords: Behavior, Geotechnics, Fusion, Resistance, Soils, Temperature.

\section{Resumen}

Introducción: El presente artículo es producto de la investigación "Transformación de suelos sometidos a procesos de fusión en el laboratorio", desarrollada en la Universidad Pedagógica y Tecnológica de Colombia en el año 2018; en este se describen los resultados obtenidos en cuanto al cambio de propiedades físicas y mecánicas de los suelos finos, en especial de los suelos arcillosos expuestos a procesos de calentamiento a diferentes temperaturas, buscando así ampliar el conocimiento de este proceso como alternativa de estabilización.

Problema: Los suelos de origen reciente son frecuentemente materiales cuyo comportamiento está ligado a la historia geológica, por lo que es común encontrar suelos que presentan problemas de baja resistencia y deformación excesiva, lo que hace necesario el "mejoramiento" de su comportamiento geotécnico.

Objetivo: El objetivo de la investigación es establecer cuantitativamente los cambios de resistencia de un suelo con granulometría fina al ser expuesto a diferentes rangos de temperatura.

Metodología: El proyecto se basó en una metodología mixta con carácter explicativo, donde se evidencian las variaciones del suelo objeto de estudio siguiendo fases expuestas dentro del presente artículo.

Resultados: Se evidencian los cambios de las propiedades físicas y mecánicas del suelo al ser fundido y sometido a diferentes ensayos, para este artículo se presentan las variaciones de los resultados del ensayo de Compresión Inconfinada y Límites de Atterberg. 
Conclusión: Analizar la eficiencia del método de estabilización con calor como una técnica de mejoramiento de suelos con composición fina, teniendo en cuenta las variaciones de la cohesión no drenada del suelo.

Originalidad: La presente investigación se realiza por primera vez en los suelos finos circundantes en la zona del depósito lacustre de la Ciudad de Tunja, Departamento de Boyacá, contribuyendo así a la caracterización geotécnica de la ciudad y a la evaluación de esta técnica de mejoramiento.

Limitaciones: Las muestras al ser fusionadas deben ser ensayadas en equipos para rocas, lo que contribuyó a que no se pudieran realizar ensayos a temperaturas superiores a las mostradas en el presente artículo.

Palabras clave: Comportamiento, Geotecnia, Fusión, Resistencia, Suelos, Temperatura.

\section{Resumo}

Introdução: Este artigo é produto da pesquisa "Transformação de solos submetidos a processos de fusão em laboratório", desenvolvida na Universidade Pedagógica e Tecnológica da Colômbia em 2018; Este descreve os resultados obtidos quanto à alteração das propriedades físicas e mecânicas de solos finos, especialmente solos argilosos expostos a processos de aquecimento a diferentes temperaturas, buscando, assim, ampliar o conhecimento deste processo como alternativa de estabilização.

Problema: Os solos de origem recente são frequentemente materiais cujo comportamento está ligado à história geológica, por isso é comum encontrar solos que apresentam problemas de baixa resistência e deformação excessiva, o que torna necessário "melhorar" o seu comportamento geotécnico.

Objetivo: 0 objetivo da pesquisa é estabelecer quantitativamente as mudanças de resistência de um solo com granulometria fina quando exposto a diferentes faixas de temperatura.

Metodologia: 0 projeto baseou-se em uma metodologia mista de caráter explicativo, onde as variações do solo em estudo são evidenciadas a partir das fases expostas neste artigo.

Resultados: São evidenciadas as alterações nas propriedades físicas e mecânicas do solo quando derretido e submetido a diferentes testes, para este artigo são apresentadas as variações dos resultados do teste de Compressão Não Confinada e Limites de Atterberg.

Conclusão: Analisar a eficiência do método de estabilização por calor como técnica de beneficiamento de solos de composição fina, levando em consideração as variações da coesão não drenada do solo.

Originalidade: Esta pesquisa é realizada pela primeira vez nos solos finos do entorno da área de depósito lacustre da Cidade de Tunja, Departamento de Boyacá, contribuindo assim para a caracterização geotécnica da cidade e a avaliação desta técnica de melhoramento.

Limitações: As amostras quando fundidas devem ser ensaiadas em equipamento de rocha, o que contribuiu para que os ensaios não pudessem ser realizados em temperaturas superiores às apresentadas neste artigo.

Palavras-chave: Comportamento, Geotécnica, Fusão, Resistência, Solos, Temperatura.

\section{INTRODUCTION}

Taking current urban development into account, it is necessary to use techniques that optimize construction processes and contribute to the economy of a region.

The development of Geotechnics, within the field of Civil Engineering, principally includes the study of the behavior of the soil that serves as a foundation or support 
for the development of a civil structure. Sometimes, the soil does not provide adequate support capacity for project construction, which is why it is necessary to draw upon soil improvement techniques that mainly contribute to improving the mechanical properties of the soil.

For this article, a soil of recent origin, obtained from manual drilling executed at a geological zone of the fluvial-lacustrine deposit of the city of Tunja, is studied, taking into account the innate mineralogical and chemical characteristics of these types of soil. The research tries to establish the change of the undrained resistance properties, considering the temperature changes in intervals between $150{ }^{\circ} \mathrm{C}$ to $650^{\circ} \mathrm{C}$; the aforementioned applies for fine-grain soils.

\subsection{Research Antecedents}

Inside this article, bibliographic citations concerning soil improvement will be referred to. These citations are described below:

In the geotechnical memory of Soil Improvement, the abstract and comparison between the primary geotechnical improvement methods of Foundation soils are established. In this memory the observation is made that soil improvement may contribute to the increase in mechanical resistance, the reduction in compressibility, the reduction of dynamic effects such as liquefaction, and the diminution in permeability and expansion, amongst others [1].

The geotechnical zoning of the city of Tunja is carried out, This zoning shows that there are two geotechnical zones defined topographically. The two zones are subdivided into zones according to their geological formations, besides, is also evident that these zones can present a consistency categorized as moderate or soft; this zoning contributed to the selection of the drilling area [2].

Tsige M and Gonzalez de Vallejo, establish the general mineralogical properties of the studied clays, and present smectite and illite as the predominant composition and in similar proportions. The general microfactory of the three zones is witnessed with some alteration, and its clayey and dense composition is evident, with consolidated and cemented materials. However, they specify that the scale of the photographs is inadequate to determine the microfactory with accuracy, this is because the photos were taken at $1.0 \mathrm{KX}$, generating loss of detail; they suggest taking photos at $2.0 \mathrm{KX}$, minimum. [3]

The Geophysical Institute of the Javeriana University, in the year 2000, developed a document of preliminary seismic studies of the city of Tunja. This document exposes the geotechnical characterization of the city, and the geological and tectonic 
conditions can be consulted. The responses of these conditions, with no doubt, depend on the resistance and mineralogical and chemical composition of the studied soils. [4]

Following this work, in 2001, a complementary paper titled Geomechanical Characterization of Soils of Tunja was made. In this complementary research, Tunja is studied geotechnically. This work helped to define the location of the representative drilling for the present research, trying to maintain similar index parameters for the heating processes. [5] and [6]

In the investigation "Experimental characterization of the Hydromechanical behavior of a compacted clay", developed in the City of Barcelona in 2007, it is documented that compacted fine soils present a factory that represents the arrangement of existing particles. This research also specifies that the presence of humidity affects compaction of the factory [7]. Nobuaki Otsuki, Wanchai Yodsudjai and Takahiro Nishida (2007), in the paper "Feasibility study on soil improvement using electrochemical technique" evaluate the change in the mineralogical and mechanical properties of a soft clay by means of electrochemistry using direct current. [8]

In the research named "Theoretical Analysis of the consolidation and deformation around gravel columns", carried out by Castro in 2008, topics about the thermal treatment of soils are indicated, the modification of the resistance properties of the studied soil are also included in the document. [9]

According to [10], the diverse compositional and textural variations of benthonic shale lithofacies are exposed, identifying the different textural features of the analyzed soils by the use of stratigraphic columns. The mineralogical study was carried out using DRX (X-ray diffraction) to establish the changes and show their mineralogical and chemical structure.

[11] helps determine the analysis that should be performed when a fluorescence test takes place. In this test, the main chemical characteristics of a sample are observed. In the Construction Processes research [12], the improvement technique with heating is shown as an option for construction techniques worldwide, establishing that this research is important in the field of engineering. In [13], related to the activation of clays from low to high temperatures, the proposal for the production of artificial pozzolans from the activation of clays as an alternative to Metakaolin is presented, in order to provide improvement to clay and obtain construction materials.

In [14] "The evaluation of the behavior of clays subjected to different times of exposure to high temperatures", periods from 1 to 15 days were defined to study whether or not the clays recovered resistance properties. Its goal was to demonstrate whether this method works as a soil stabilization method. Among the results 
obtained, a series of graphs are presented, showing the increase or decrease in the evaluated parameters.

Taking into account the mineralogical component of the present investigation, the documents considered as the source for this purpose are presented below. In the document named "Clay mineralogy and calcareous nannofossils from Jagüel and Rock formations in the eastern sector of Pellegrini Lake, Neuquen Basin, Argentinian Republic" [15] is established the new mineralogical, sedimentological and micropaleontological data of the formations studied in the consulted paper, describing the microfactory and the mineralogy of the fangolites. It is shown that the clay minerals have a detrital origin, with a predominance of smectites.

In the 2012 document entitled "Soil Stablization Methods and Materials" by Makusa [16], the method of improving soils with temperature action is recognized as one of the techniques that can improve the resistance properties of a soil with excessive deformations. In the article named "The Uncertainties of Using Replacement Soil in Controlling Settlement", the research is generated taking into account the quality of the soils of Egypt, where there is a layer of soft soil that must be necessarily improved to construct high-rise buildings. [17]

"Evaluation of the efficiency of different ground improvement techniques" investigates the performance of different procedures for the improvement of soft soils, using a three-dimensional model and evaluating the change in the physical properties of the soil under study. [18]. "Assessment of Heat Treatment on Clays Mixed with Silica Sand", Malaysia, 2014, examines the effects of heat treatment on two types of clays mixed with silica sand under laboratory conditions. The soils were exposed to three temperatures: 100, 250 and $500{ }^{\circ} \mathrm{C}$. The properties of the tested soils were: The Atterberg limits, optimal humidity and resistance to unconfined compression. Experimental outcomes revealed that a temperature greater than $100{ }^{\circ} \mathrm{C}$ reduces Atterberg limits, optimum water content and unconfined compressive strength. [19]

In the document entitled "Evaluation of the Geomechanical Behavior of Clays in the Campo Alegre Sector - City of Barranquilla", 2014, the treatment and improvement to the Barranquilla clays are specified. Initially, the framework is established for partially saturated soils; the experimental program to make physical and microstructural characterization of the clay. Finally, the primary characteristics of the clays and their improvements are determined. [20]

Inthe 2014, research of the NationalUniversity of Colombia entitled "Improvement of fine soils from electroosmosis", the electroosmosis system is settled and analyzed, performing tests on fine soils using electrical currents in the laboratory, associating the results with the geomechanical parameters obtained with other tests. Finally, 
it is concluded that "The resistance in the analyzed samples increased due to the electroosmosis process, in a ratio of 1:1.3 to 1:11, measured in unconfined compression and vane tests, respectively". [21]

In the master's degree thesis entitled "Evaluation of the concentration of lead and cadmium in surface soils of parks and public squares in three municipalities of the Monterrey Nuevo Leon metropolitan area", it is established that x-ray fluorescence is necessary to determine the concentration of metals in the analyzed soils; some relations between this test and the atomic absorption test are mentioned. [22]

In the city of Tunja, studies have helped understand the characterization of the soils of the city. These studies are a major base for the present investigation. In 2015 the Geodynamic Characterization for the seismic micro-zoning of the city of Tunja, Sector 2 and 3, was implemented (Pedagogical and Technological University of Colombia). There are laboratory results of the classification and resistance tests of the Lacustrine deposit in the city; results that are used as input and verification parameters for the present investigation. [23]

In the 2015 study named "The micro-factory of clays analyzed using the SEM test", changes in the combination of the clays with distilled water are analyzed. It is evident that it has a honeycomb or reticulated micro-factory, forming face-face and face-edge joints, the mentioned study is a really important example for the present investigation [24]. Taking into account that foundation soils may experience unfavorable deformations to civil works, in the article "Soil Improvement Techniques" [25], the different improvement methods are presented in order to increase the bearing capacity and reduce deformations of the soils. Heating methods (thermal) are enunciated to increase their resistance properties.

In the experimental article "Evaluation of the behavior of Sandy Soil - Cement Mixture", techniques for soil improvement are defined in order to contribute with the enhancement of its mechanical properties and, consequently, to the modification of its primary properties, by means of laboratory tests. [26]. In "Ground Improvement Techniques to Enhance the Bearing Capacity of weak Soil", 2009, it mentioned that during the construction process of a civil work, it is often found that the foundation soil is not appropriate for the work, finding the soil in a weak state. As a result, the author quotes different soil improvement procedures to improve the bearing capacity of the foundation soil. [27], [28].

According to the bibliographic review cited above, it is well-defined that this research is aligned with current trends in soil enhancement, contributing with this investigation to explore an improvement technique through soil fusion, analyzing the 
change in resistance properties of a soil for the city of Tunja, Boyacá, Colombia; a methodology that has not been studied so far.

\section{MATERIALS AND METHODOLOGY.}

\subsection{Soil Type}

In order to present the results shown in the subsequent items, the material object of the present investigation is presented below. Initially, a soil with fine granulometry is considered, characterized according to the table shown below.

Table 1. Characteristic of the studied soil.

\begin{tabular}{cc}
\hline Parameter & Result \\
\hline Natural humidity (Wn) & $61.1 \%$ \\
\hline Plastic limit (LP) & $47.48 \%$ \\
\hline Liquid limit (LL) & $23.68 \%$ \\
\hline Plasticity index (IP) & $23.8 \%$ \\
\hline Specific Gravity (Gs) & 2.68 \\
\hline Undrained Cohesion (Cu) & $0.9 \mathrm{~kg} / \mathrm{cm}^{2}$ \\
\hline Angle of Internal Friction $(\phi)^{* *}$ & $28^{\circ}$ \\
\hline Undrained Cohesion (Cu) & $2.4 \mathrm{~kg} / \mathrm{cm}^{2}$ \\
\hline
\end{tabular}

* Unconfined Compression Test.

** CU Direct Cut Test.

Source: own work

\subsection{Methodology}

Following, the research phases to achieve the results presented in the next section are described, developing a mixed methodology with an explanatory approach to the variation of the resistance properties of the analyzed soil with temperature variations. [14]

\section{- Initial phase:}

In this process, the exploration of the subsoil was made using manual drilling, obtaining unaltered samples to perform the mechanical tests, and altered samples for the classification test. After the exploration phase, the extraction 
of unaltered samples, obtained using thin-walled tubes (Shelby type), was completed.

\section{- Experimental phase:}

Once the samples were obtained, laboratory tests were executed, with classification tests initially; later, the soil was characterized by mechanical tests. Heat application stage: Considering the extraction of unaltered samples, the heat application stage was implemented, in a range of $150{ }^{\circ} \mathrm{C}$ to $650^{\circ} \mathrm{C}$. Temperatures up to $550{ }^{\circ} \mathrm{C}$ were obtained with furnaces located at the Geotechnical laboratory. When it was necessary to apply higher temperatures, metallurgical equipment muffles, above $550^{\circ} \mathrm{C}$ capacity, were used.

Execution of tests on samples subjected to fusion processes: Once the samples were "melted", classification and mechanical tests were finished to demonstrate the changes obtained.

\section{- Analysis phase}

The analysis of the results was prepared with the information acquired in the experimental phase. In this analysis, graphs are used to show the change in the different properties associated with the variation in temperature.

\section{RESULTS}

The results obtained after the application of melting and unconfined compression tests on the considered soil are presented, implementing the aforementioned methodology. All results were obtained using unaltered samples.

\subsection{Soil in the Natural State}

The sample, has a medium consistency in its natural state, presents an LL of $47.5 \%$ and an LP of $23.7 \%$, its unconfined compressive strength presents a value of $1.8 \mathrm{~kg} /$ $\mathrm{cm}^{2}$, with a value of Undrained Cohesion of $0.9 \mathrm{~kg} / \mathrm{cm}^{2}$. These data are presented in Table 1. Figure 1 shows a sample with fine predominance and plastic behavior. 


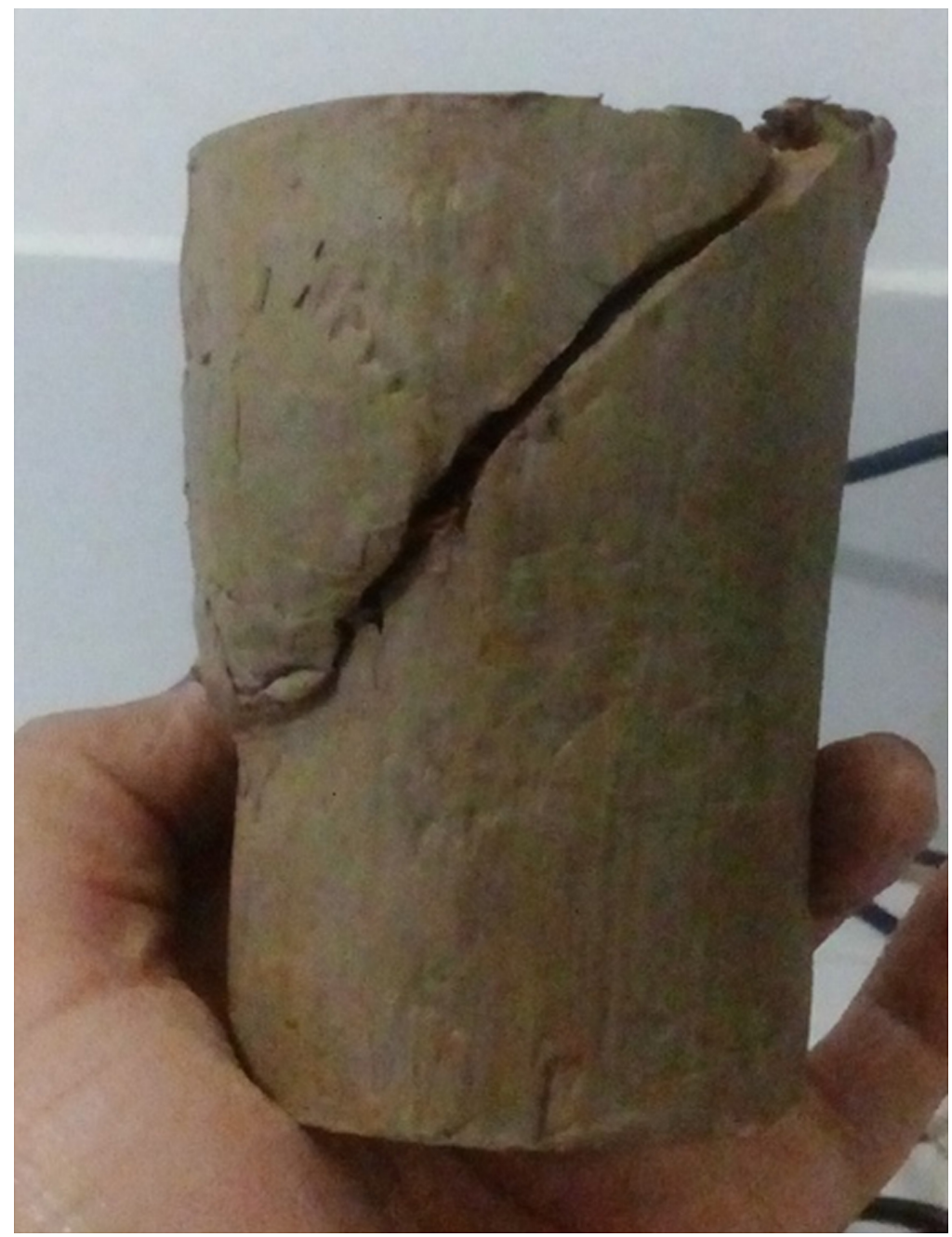

Figure 1. Unconfined compression test. Sample in natural state. Source: own work

\subsection{Soil exposed to $150^{\circ} \mathrm{C}$}

The exposed sample has a middling consistency, presents an LL of $54.5 \%$ and an LP of $28.1 \%$, the unconfined compressive strength presents a value of $32.8 \mathrm{~kg} / \mathrm{cm}^{2}$, with an undrained cohesion value of $16.4 \mathrm{~kg} / \mathrm{cm}^{2}$. Figure 2 displays a sample of soil with a fragile behavior. 


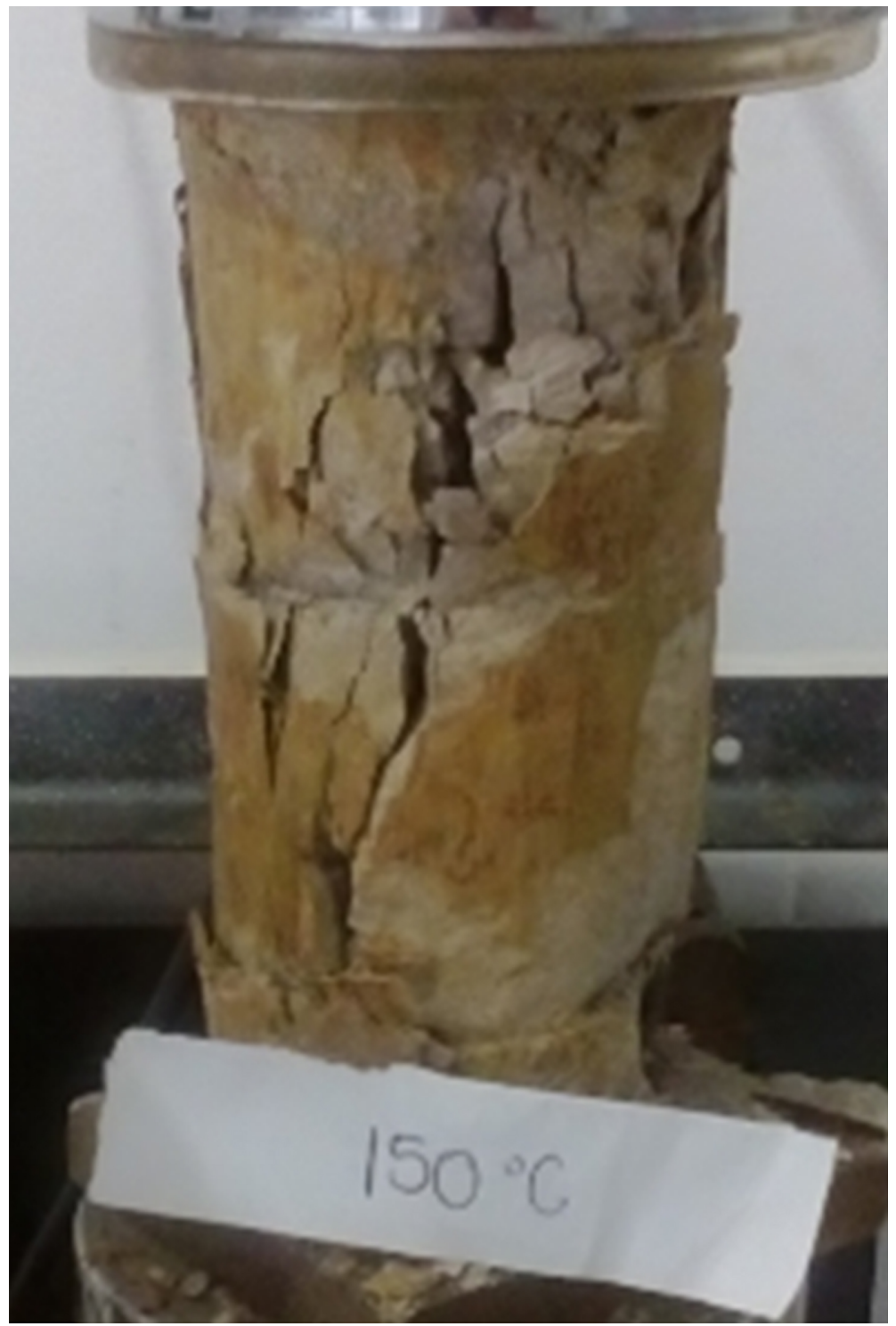

Figure 2. Unconfined compression test. Sample Fused $150^{\circ} \mathrm{C}$. Source: own work

\subsection{Soil exposed to $350^{\circ} \mathrm{C}$}

The sample subjected to this temperature has an average consistency, has an $L L$ of $45.01 \%$ and an LP of $25.3 \%$, the unconfined compressive strength has a value of 9.9 $\mathrm{kg} / \mathrm{cm}^{2}$, with an undrained cohesion value of $5.0 \mathrm{~kg} / \mathrm{cm}^{2}$. A sample with fragile behavior and vertical cracking is obtained when the soil is subjected to $350{ }^{\circ} \mathrm{C}$; see Figure 3 . 


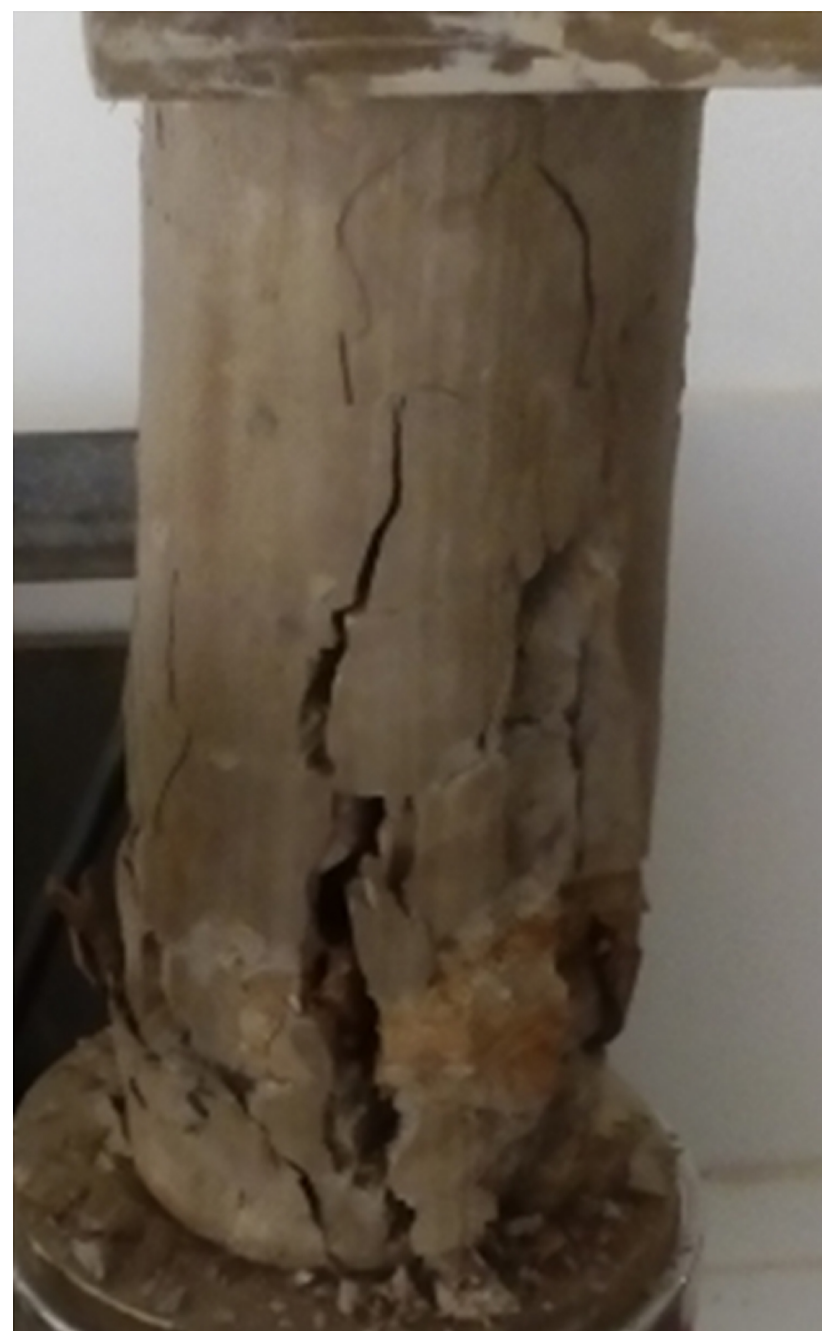

Figure 3. Unconfined compression test. Sample fused $350^{\circ} \mathrm{C}$. Source: own work

\subsection{Soil subjected to $550^{\circ} \mathrm{C}$}

The sample for this test has a medium consistency, with an LL of $43.9 \%$ and an LP of $24.8 \%$, unconfined compressive strength of $6.6 \mathrm{~kg} / \mathrm{cm}^{2}$ and undrained cohesion of 3.3 $\mathrm{kg} / \mathrm{cm}^{2}$. Bearing in mind the behavior evidenced in Figure 4 (sample subjected to 550 $\left.{ }^{\circ} \mathrm{C}\right)$, the fragile behavior continues, with crumbling of its fine particles. 


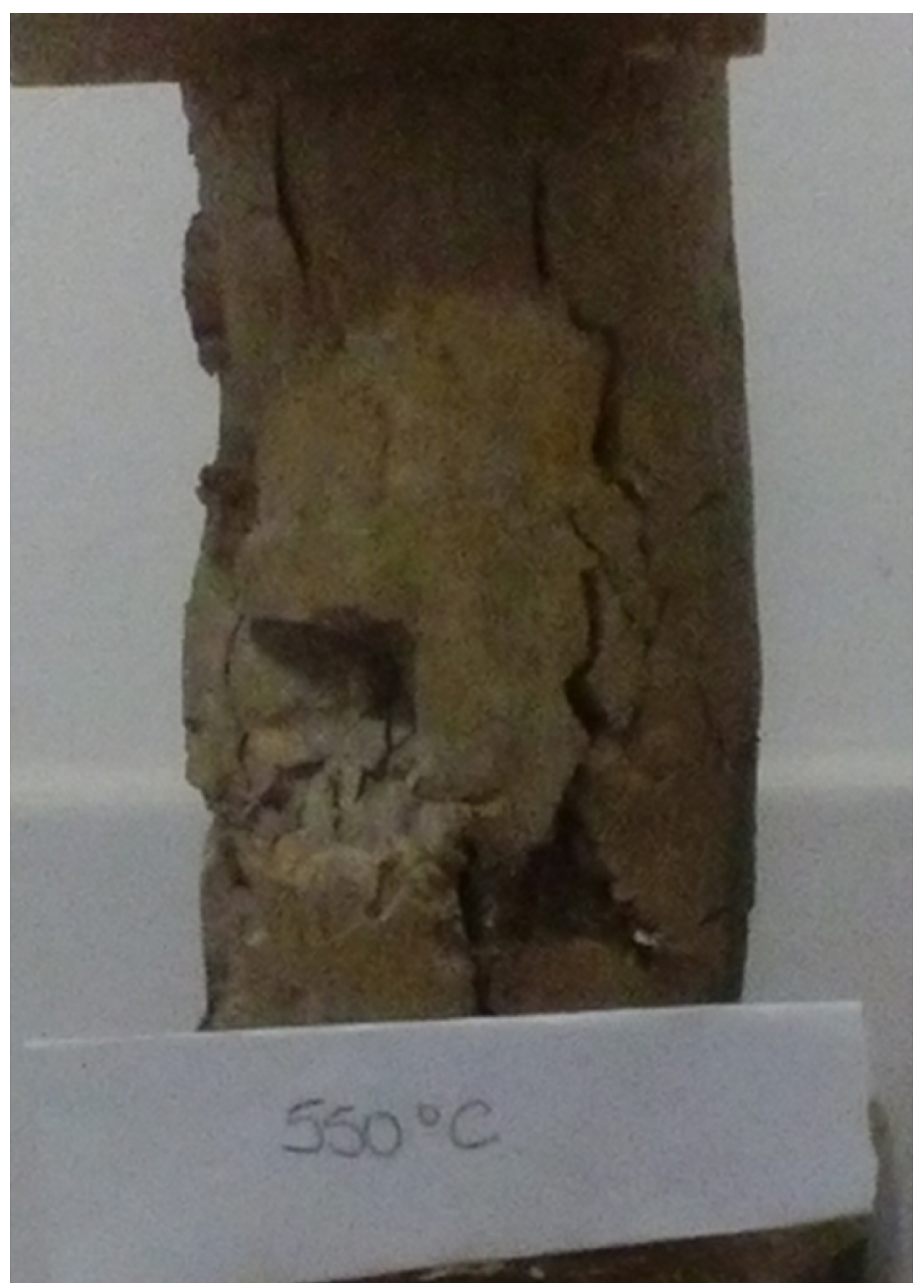

Figure 4. Unconfined compression test. Sample Fused $550{ }^{\circ} \mathrm{C}$. Source: own work

\subsection{Soil subjected to $650^{\circ} \mathrm{C}$}

The sample subjected to this temperature has an average consistency, shows an LL of $42.6 \%$ and an LP of $24.3 \%$, the unconfined compression resistance during a 2 -hour fusion process using muffles has a value of $11.5 \mathrm{~kg} / \mathrm{cm}^{2}$, with an undrained cohesion value of $5.7 \mathrm{~kg} / \mathrm{cm}^{2}$. After 4 hours, the sample has a value of $14.9 \mathrm{~kg} / \mathrm{cm}^{2}$, with a value of undrained cohesion of $7.5 \mathrm{~kg} / \mathrm{cm}^{2}$. Finally, after 8 hours of exposure to 650 ${ }^{\circ} \mathrm{C}$, this sample presents a value of $5.6 \mathrm{~kg} / \mathrm{cm}^{2}$, with an undrained cohesion value of $2.8 \mathrm{~kg} / \mathrm{cm}^{2}$. 


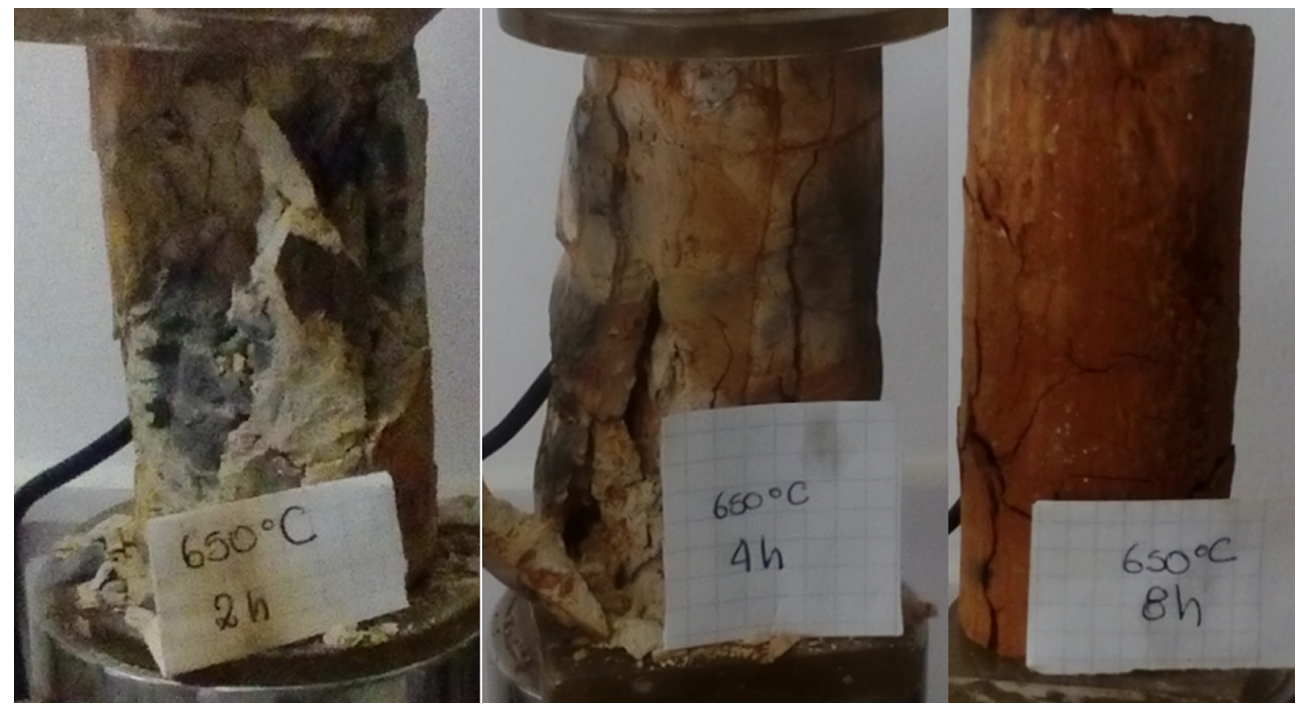

Figure 5. Unconfined compression test. Sample Fused $650^{\circ} \mathrm{C}$. Source: own work

The samples maintain a fragile behavior when subjected to a temperature of $650^{\circ} \mathrm{C}$; A sample with 8 hours of fusion exposure has a hard consistency and presents a vertical cracking process. For this sample, a change in color is observed concerning the initial condition.

\section{DISCUSSION}

Taking into consideration the results of the laboratory tests, it is stated that the resistance properties of the soils experience changes. In addition, the "fusion" produces variations in their Atterberg limit values; these results are indicated in tables 2 and 3.

\subsection{Atterberg limits.}

\section{- Variation of the Liquid Limit (LL).}

Table 2 and Figure 6 show the results obtained after the experimental phase, wherein the Atterberg limit tests were completed. According to the result of these tests, Liquid Limit varies between $39.4 \%$ and $54.5 \%$. It is observed that for the initial conditions, an $\mathrm{LL}$ of $47.48 \%$ for the temperature of $150{ }^{\circ} \mathrm{C}$ with a melting time of 12 hours, attains an LL of $54.45 \%$; the highest value in the series of tests analyzed. The maximum temperature produces the lowest $L L$, with a value of $39.4 \%$, and a reduction of the $L L$ by $17 \%$, approximately. 
Table 2. Atterberg limits

\begin{tabular}{cc}
\hline TEMPERATURE $\left({ }^{\circ} \mathbf{C}\right)$ (Time) & LL $(\%)$ \\
\hline 0 (Natural) & 47.48 \\
\hline 150 (12 hours) & 54.45 \\
\hline 350 (12 hours) & 45.01 \\
\hline 550 (12 hours) & 43.92 \\
\hline 650 (2 hours) & 42.55 \\
\hline 650 (4 hours) & 41.34 \\
\hline 650 (8 hours) & 39.4 \\
\hline
\end{tabular}

Source: own work

Figure 6 illustrates that at a temperature of $150{ }^{\circ} \mathrm{C}$, the undrained cohesion acquired with unconfined compression test registers the highest value, and from the temperature increase, with a range between 350 to $650{ }^{\circ} \mathrm{C}$, the resistance of the undrained cohesion experiences a decrease.

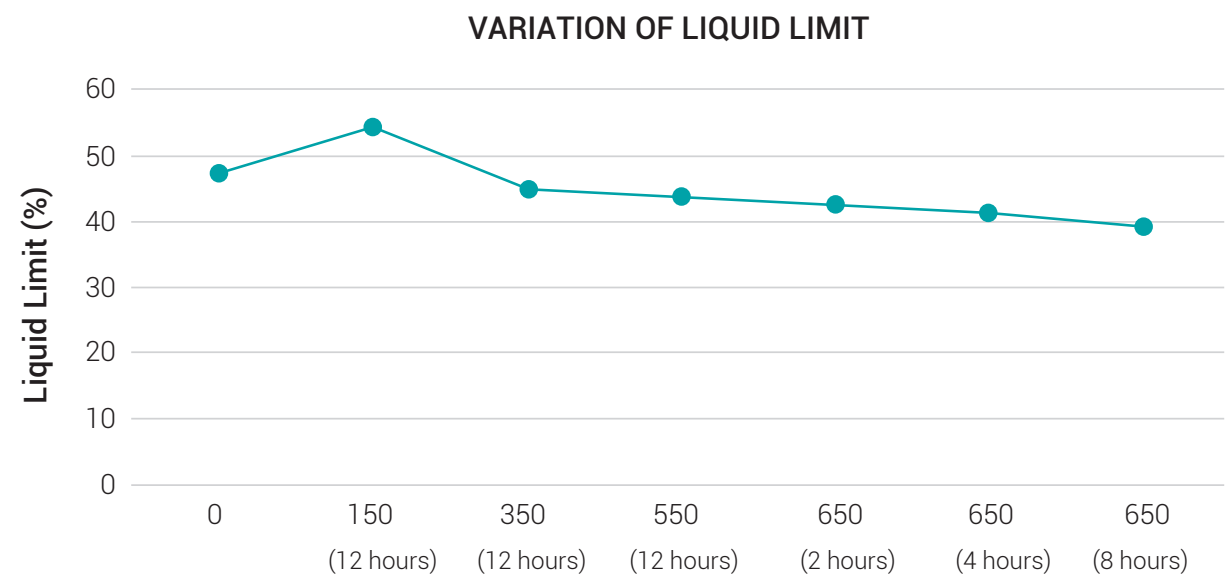

Temperature $\left({ }^{\circ} \mathrm{C}\right)$

Figure 6. Variation of the Liquid Limit (LL).

Source: own work

In the previous graphic, an important variation in the Liquid Limit is exhibited, with a $17 \%$ reduction (from an LL value of $47.48 \%$ to $39.4 \%$ ). This variation produces changes in the mineralogical, chemical and geotechnical properties of the sample. 


\section{- Variation of the Plasticity Limit (LP).}

As for the plasticity limit (LP), a parameter that specifies the property of soil to modify its consistency, Table 3 shows that at a temperature of $150{ }^{\circ} \mathrm{C}$, the soil presents an LP of $28 \%$, registering an increase in this property according to the initial condition of the examined soil. However, from this temperature, a decrease in this parameter is noted, indicating that the higher the temperature, the lower the possibility that a soil suffers volumetric changes; this suggests that the soil may suffer "enhancement" in terms of its expansion condition.

Table 3. Variation of the Plasticity Limit (LP).

\begin{tabular}{cc}
\hline TEMPERATURE $\left({ }^{\circ} \mathbf{C}\right)$ (Time) & LP (\%) \\
\hline 0 (Natural) & 23.68 \\
\hline 150 (12 hours) & 28.13 \\
\hline 350 (12 hours) & 25.29 \\
\hline 550 (12 hours) & 24.8 \\
\hline 650 ( 2 hours) & 23.4 \\
\hline 650 (4 hours) & 22.6 \\
\hline 650 (8 hours) & 19.3 \\
\hline
\end{tabular}

Source: own work

This change of the plasticity limit can be perceived graphically in Figure 7 . Besides, it can be observed that when the exposure time is modified to 2 hours, at $650{ }^{\circ} \mathrm{C}$, a greater value of LP is reached for the same temperature, but with an exposure time of 8 hours, this points out the incidence of the heat time exposure on the reduction of the plasticity of the soil. Considering the variation of the Plasticity Limit, it can be demonstrated that this limit has a linear tendency of decreasing, starting at $350{ }^{\circ} \mathrm{C}$. Although its changes are slight, these can influence radically in the bearing capacity of the analyzed soil. 
VARIATION OF THE PLASTICITY LIMIT

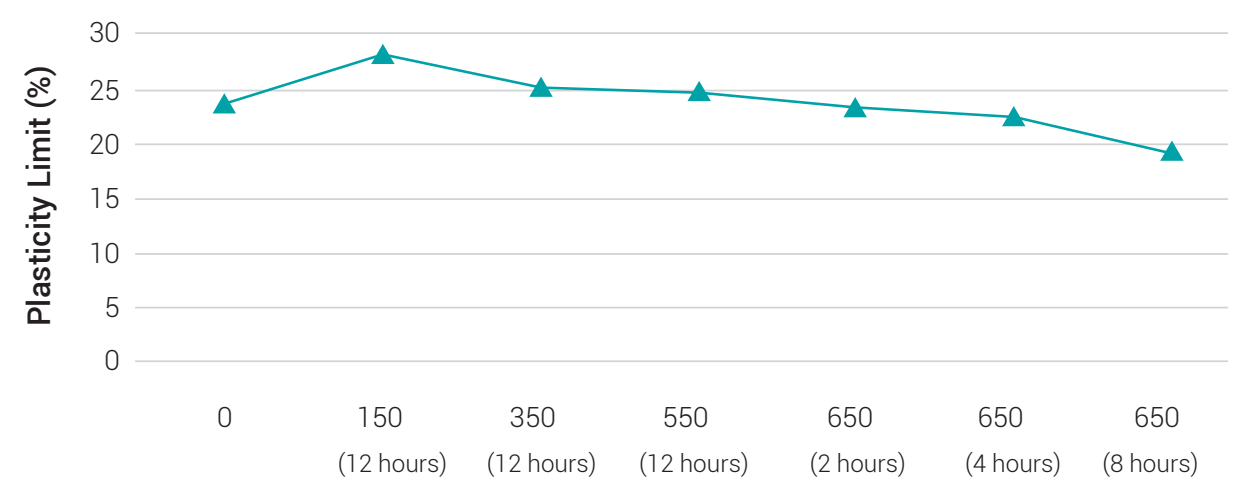

Temperature $\left({ }^{\circ} \mathrm{C}\right)$

Figure 7. Variation of the Plasticity Limit (LP).

Source: own work

\section{- Plasticity Index (IP)}

A relevant indicator of a soil is the Plasticity Index. This index is the result of the difference between the Liquid Limit and the Plasticity Limit. According to the above, the results for the IP are presented in Table 4.

Table 4. Variation of the Plasticity Index.

\begin{tabular}{cc}
\hline TEMPERATURE $\left({ }^{\circ} \mathbf{C}\right)$ (Time) & IP $(\mathbf{\%})$ \\
\hline NATURAL & 23.8 \\
\hline 150 (12 hours) & 26.32 \\
\hline 350 (12 hours) & 19.72 \\
\hline 550 (12 hours) & 19.12 \\
\hline 650 ( 2 hours $)$ & 19.15 \\
\hline 650 (4 hours) & 18.74 \\
\hline 650 (8 hours) & 20.1 \\
\hline
\end{tabular}

Source: own work

For this property, the tendency is to increase at $150{ }^{\circ} \mathrm{C}$ and to decrease with further increments of temperature. However, it is manifested that for a temperature of $650^{\circ} \mathrm{C}$ and a heating time of 8 hours, this index has a small increase. 


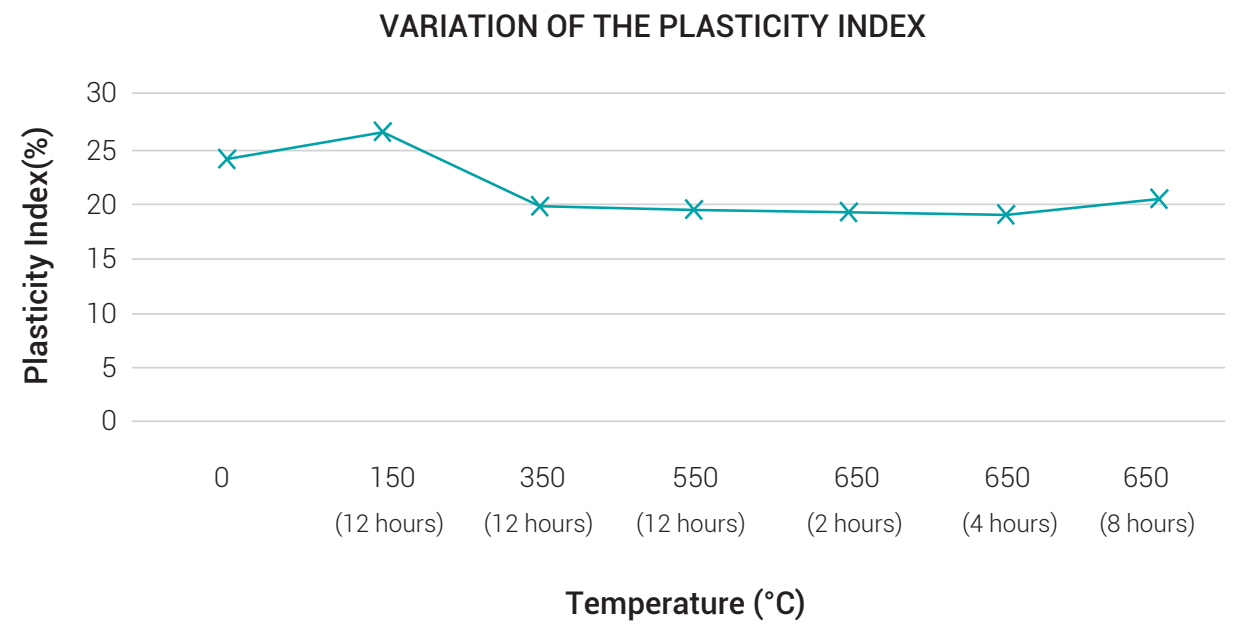

Figure 8. Variation of the Plasticity Index (IP).

Source: own work

\subsection{Undrained Cohesion (Cu)}

One of the most important reference properties associated with soil geotechnical improvement is the cohesion of the soil particles in terms of their internal forces. This parameter is commonly associated with fine consistency soils, the results achieved in this research are presented in Table 5.

Table 5. Resistance Properties, Undrained Cohesion (Cu)

\begin{tabular}{|c|c|c|}
\hline TEMPERATURE $\left({ }^{\circ} \mathrm{C}\right)$ (Time) & Qu $\left(\mathrm{kg} / \mathrm{cm}^{2}\right)$ & $\mathrm{Cu}\left(\mathrm{kg} / \mathrm{cm}^{2}\right)$ \\
\hline 0 (Natural) & 1.8 & 0.9 \\
\hline 150 (12 hours) & 32.79 & 16.4 \\
\hline 350 (12 hours) & 9.91 & 5 \\
\hline 550 (12 hours) & 6.56 & 3.3 \\
\hline 650 (2 hours) & 11.48 & 5.7 \\
\hline 650 (4 hours) & 14.93 & 7.5 \\
\hline 650 (8 hours) & 5.55 & 2.8 \\
\hline
\end{tabular}

Source: own work

In the development of the research, variations in the undrained cohesion were observed, for this parameter, the sample starts with a magnitude of $0.9 \mathrm{~kg} / \mathrm{cm}^{2}$, reaching the highest resistance value at a temperature of $150{ }^{\circ} \mathrm{C}$, whilst for $650^{\circ} \mathrm{C}$ and 
2 hours of exposure time, the cohesion value declines, For the same temperature $\left(650^{\circ} \mathrm{C}\right)$ the maximum value of cohesion is attained after 4 hours of exposure.

\section{Variation of the Undrained Cohesion (Cu)}

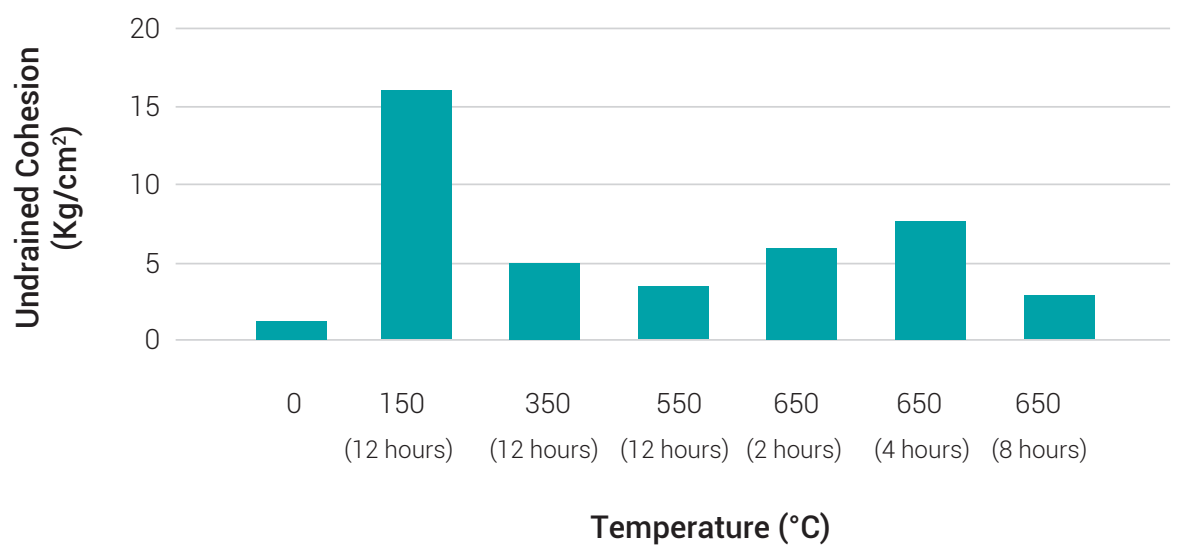

Figure 9. Variation of the Undrained Cohesion (Cu).

Source: own work

In this investigation, the undrained cohesion property presented the greatest variation in the fusion tests performed, reaching variations close to $90 \%$ of the maximum resistance attained at $150{ }^{\circ} \mathrm{C}$. These variations evidence the internal confinement of the particles at certain temperatures.

\section{CONCLUSIONS.}

Afterward the completed tests and the methodology used, the following conclusions are obtained:

The soil of the city of Tunja, in the lacustrine deposit zone, has a predominantly fine composition, its origin and composition create a soil prone to deformations due to load application. This behavior can be modified by subjecting the soil to high temperatures, with ranges higher than $150{ }^{\circ} \mathrm{C}$.

To modify the resistance parameters of soil, specifically the undrained cohesion, it is manifest that this property is altered by exposing the soil to high temperatures. The results of the implemented tests indicate that the undrained cohesion is reduced by temperatures over $200^{\circ} \mathrm{C}$, but reaches its highest value at $150{ }^{\circ} \mathrm{C}$.

The plasticity condition is closely associated with the test temperature. This property is lost when time and the temperature are increased; that is, the higher the 
temperature the lower plasticity of the soil. This condition contributes to a fragile behavior of the soil when loads are applied.

Fine soils have a tendency to experience significant volumetric changes; a condition related to their mineralogical, chemical and physical composition. Therefore, it is crucial to consider these variables in the study of clayey soil, bearing in mind its transformation during the different stages of heat application.

Soil in natural conditions presents an average resistance. This circumstance causes cost overruns in the construction of different civil structures. Keeping this in mind, it is noticeable that heat treatment improves the soil properties and therefore its bearing capacity.

The thermal shock inherent in the removal of the samples from the muffle had special attention during the realization of the laboratory tests, because on many cases the samples could present cracks; this condition will undoubtedly modify the resistance to unconfined compression.

In general, it is witnessed that the consistency limits vary with increasing temperature, presenting a behavior that is practically constant. This behavior indicates that the higher the temperature, the lower the value of the Atterberg limits.

\section{REFERENCES}

[1] A. L. Ruiz, "Mejora Geotecnica del suelo," Informes de la Construcción, vol. 35, no. 354, pp. 37-49, 1983, doi: https://doi.org/10.3989/ic.1983.v35.i354.2001.

[2] O. Ramirez, "Zonificación Geotecnica de la ciudad de Tunja,"UPTC, Tunja, 1990. P 30-40.

[3] M. y. G. d. V. Tsige, "Microfábrica y mineralogía de las arcillas azules del Guadalquivir," España, 1998. [Online]. Available: http://www.sociedadgeologica.es/archivos/geogacetas/ Geo20\%20(6)/Art23.pdf. P 1324-1327.

[4] T. M. A. y. et, "Estudios de Amenaza y microzonificacion Sismica, Vulnerabilidad Estructural y evaluacion de Escenarios de Daño," Bogota, 2000. [Online]. Available: https://repositorio.gestiondelriesgo.gov.co/bitstream/handle/20.500.11762/19836/Microzonificacion Sismicalbague\%28UJaveriana_2000\%29.pdf?sequence=1\&isAllowed=y. P 1-33.

[5] R. A. y. L. L., “Caracterización Geomécánica de Tunja Sector 1, UPTC-2001. P. 55-60," Tunja, 2001. 
[6] M. y. V. J. Montes, “Caracterización Geomecánica de Tunja Sector 2," UPTC, Tunja. P 33, 2001.

[7] C. M. B. Berzunza, "Caracterización experimental del comportamiento Hidromecanico de una arcilla compactada," Barcelona, 2007. [Online]. Available: https://upcommons.upc.edu/ bitstream/handle/2117/93562/04CMbb04de13.pdf?sequence=4\&isAllowed=y. P 1-10.

[8] W. Y. T. N. Nobuaki Otsuki, "Feasibility study on soil improvement using electrochemical technique," Construction and Building Materials, vol. 21, no. 4, pp. 1046-1051, 2007, doi: https://doi.org/10.1016/j.conbuildmat.2006.02.001 . P. 1046-1051.

[9] J. Castro González, "Análisis teórico de la consolidación y deformación alrededor de columnas de grava," Santander, 2008. [Online]. Available: https://www.tesisenred.net/handle/10803/10604;jsessionid=8A6AB68877DB3F2A2084E1AEDF31921F. P. 1-46.

[10] J. A. M. N. J. C. J. A. M. R. M. Pozo Gómez, "Textural and compositional characteristics of magnesic clay deposits in the Madrid basin," Boletin Geologico y Minero ISSN: 0366-0176, vol. 112, no. 4, p. 15, 2001, doi: https://doi.org/10.3390/min8100418. P. 15.

[11] M. C. Valentinuzzi, "Análisis por fluorescencia de rayos X: Implementacion de guias de haces en reflexion total," Cordoba, 2008. [Online]. Available: http://documents.famaf.unc.edu.ar/ publicaciones/documents/serie_d/DFis130.pdf. P. 1-111.

[12] J. Chu, "Construction Processes," Conferencia Internacional sobre Mecánica de Suelos e Ingeniería Geotécnica, pp. 3006-3214, 2009. [Online]. Available: https://www.researchgate. net/publication/258311283_construction_processes.

[13] R. F. M. A. K. S. A. A. J. F. M. Rancés Castillo, "Activación de arcillas de bajo grado a altas temperaturas," Revista ingeniería de construcción, vol. 25, no. 3, p. 23, 2010, doi: http://dx.doi. org/10.4067/S0718-50732010000300001.

[14] H. A. Rondón, "Behavior Evaluation of clays subjected to different exposures times at high Temperatures," Revista EIA, vol. 1, p. 13, 2011. [Online]. Available: http://www.scielo.org.co/ scielo.php?script=sci_arttext\&pid=S1794-12372011000200014\&lng=en\&nrm=iso.

[15] A. C.,. G. P. Telma Musso, "Clay mineralogy and calcareous nannofossils from Jagüel and Roca formations in the eastern sector of Pellegrini Lake, Neuquen Basin, República Argentina," Revista Geológica de Chile, vol. 39, no. 3, p. 32, 2012, doi: http://dx.doi.org/10.5027/andgeo v39n3-a08. 
[16] G. P. Makusa, "Soil Stabilization methods and Materials," de Soil Stabilization methods and Materials, Luleå, Sweden, Department of Civil, Environmental and Natural resources engineering, 2012, p. 38.

[17] A. K. Gabr, "The Uncertainties of Using Replacement Soil in Controlling Settlement," Journal of American Science 2, vol. 8, no. 12, pp. 662 , 666, 2012, doi: doi:10.7537/marsjas081212.91.

[18] N. El y S. Bryson, "Techniques, Evaluation of the efficiency of different ground improvement," In 18th International Conference on Soil Mechanics and Geotechnical Engineering, vol. 2, no. 6, pp. 2-5, 2013. [Online]. Available: http://www.cfms-sols.org/sites/default/files/Actes/683 $-686 . p d f$.

[19] M. R. T. A. A. F. T. A. Akbar Firoozi, "Assessment of Heat Treatment on Clays Mixed with Silica Sand," Australian Journal of Basic and Applied Sciences, vol. 8. [Online]. Available: https:// www.researchgate.net/publication/287999437_Assessment_of_heat_treatment_on_clays_ mixed_with_silica_sand, nº19, p. 5, 2014.

[20] E. A. R. Castiblanco, "Evaluación del Comportamiento Geomecánico de Arcillas en el Sector de Campoalegre - Ciudad de Barranquilla," Bogota, 2014. [Online]. Available: http://bdigital. unal.edu.co/46799/1/299993.2014.pdf. P 1-154.

[21] L. E. R. Mosquera, "Mejoramiento de suelos finos a traves de electroosmosis," Bogotá, 2014. [Online]. Available: http://bdigital.unal.edu.co/46800/1/8280161.2014.pdf. P. 1-137.

[22] V. R. d. I.P. Cerdad, "Evaluación de la concentración de plomo y cadmio en suelo superficial de parques y plazas públicas en tres Municipios del area metropolitana de Monterrey y nuevo coIon Mexico," Monterrey, 2014. [Online]. Available: http://eprints.uanl.mx/4119/1/1080253816. pdf. P. 100-150.

[23] R. F. y. G. Leonardo, "Caracterización Geodinámica para la microzonificación sísmica de la ciudad de Tunja, Sector 2 y 3," 2015. P 60-86.

[24] M. I. C. (. at), "Estudio de la Microfábrica de Tres Arcillas Españolas para su posible uso en peloterapia," Revista de la sociedad española de mineralogía, no. 17, pp. 37-38, 2013. [Online]. Available: http://www.ehu.eus/sem/macla_pdf/macla17/Macla17_037.pdf.

[25] M. B. M. Gaafer, "Soil Improvement Techniques," International Journal of Scientific \& Engineering Research, vol. 6, no. 12, pp. 217 - 222, 2015. [Online]. Available: http://www.ehu. eus/sem/macla_pdf/macla17/Macla17_037.pdf. 
[26] M. S. Hassan Sharafia, "Experimental evaluation of the behavior of Sandy Soil-Cement Mixture," Revista Ingeniería UC, vol. 26, no. 3, pp. 258 - 272, 2019. [Online]. Available: http://bdigital2.ula.ve:8080/xmlui/bitstream/handle/654321/4076/art02.pdf?sequence=1\&isAllowed=y.

[27] D. S. M. D. Hukma Ram, "Ground Improvement Techniques to Enhance the Bearing Capacity of weak Soil," International Journal of Research and Analytical Reviews, vol. 6, no. 2, pp. 696700, 2019. [Online]. Available: http://www.ijrar.org/papers/IJRAR19D1098.pdf.

[28] S. A. Vaca, E. Serrano Vivas, y J. E. Rangel Díaz, "Ingeniería inversa para dispositivos electrónicos: estado de temperatura y humedad del suelo," Vis. Electron., vol. 13, no. 1, pp. 123-134, ene. 2019, doi: https://doi.org/10.14483/22484728.14404 